\title{
CRITICAL REVIEW OF RESEARCH EVIDENCE OF PARENTING COORDINATION'S EFFECTIVENESS
}

\section{Robin M. Deutsch, Gabriela Misca and Chioma Ajoku}

\begin{abstract}
Parenting coordination (PC) has been in use since the mid-1980s, but research on its effectiveness is sorely lacking. We review the extant research organized by three themes: (1) parenting coordinators' perceptions of their role and function; (2) professionals' and parents' views and perceptions of PC; and (3) outcomes of PC, including some measures of effectiveness of the PC process. While these studies provide some insight into PC effectiveness, there is still a lack of research that uses objective out- come measures of efficacy and that considers characteristics of the co-parent dyad, personality difficulties, or the professional discipline of the parenting coordinator. Future research recommendations are discussed.

\section{Key Points for the Family Court Community}

- While parenting coordination (PC) is perceived by professionals to be effective, the research on PC effectiveness is limited by a small number of studies of variable quality; therefore there is no robust evidence of its effectiveness in practice.

- There is a need for research on PC effectiveness that considers parent engagement, conflict level, and personality variables as well as professional discipline of the parenting coordinator.

- While the Association for Family and Conciliation Courts and the American Psychological Association guidelines provide a model for PC practice, there is a distinct lack of theoretical underpinning of the PC practice.

- It is imperative for professionals and researchers to collaborate toward the development of a unified theoretical model to inform the PC role and practice, which in turn will allow objective assessment of its effectiveness.
\end{abstract}

Keywords: Alternative Dispute Resolution; Co-parenting; Divorce; High Conflict; Parenting Coordination; and Parenting Coordinator. 
Cite as: $\quad$ Deutsch, M.R., Misca, G. and Ajoku, C. (2018) Critical review of research evidence of parenting coordination's effectiveness, Family Court Review, 56(1).

\section{INTRODUCTION}

Parenting Coordination (PC) is an alternative dispute resolution role, often ordered by the court or by stipulated agreement, that combines functions of education, assessment, case management, facilitative negotiation, conflict resolution, mediation and decision making to help parents implement their existing parenting plan, comply with the terms of the plan, and resolve disputes in a timely manner. The term "Parenting Coordination" was first used in Colorado in the early 90's (Baris et al., 2001). However, the role and process have been used, often under different names, such as Special Master or Parenting Time Expeditor in the US and Canada since the mid 1980's. The practice emerged at the time in response to the growing family court caseloads, repeated conflicts and ongoing litigation among high conflict parents post decree, and the growing evidence of the harmful effects of high conflict on children (Coates, Deutsch, Starnes, Sullivan, \& Sydlik, 2004; Kelly, 2014).

A parenting coordinator is usually a mental health or legal professional who is courtordered or mutually agreed upon to help the co-parents reduce conflict between them, implement and monitor a safe and workable parenting plan, decrease use of the courts for litigation to resolve their child-related disputes in a timely manner, and improve co-parenting by raising their skill level in communication, conflict resolution, and decision making. Unlike many other clinical and legal interventions, the PC role is highly structured with distinct roles and functions as described in guidelines and where authorized by law, statute or rule, with a clear scope of authority and rigorous training requirements. However, not all jurisdictions have legal authority to appoint PCs, leaving the practice unregulated in those areas. 
Cite as: $\quad$ Deutsch, M.R., Misca, G. and Ajoku, C. (2018) Critical review of research evidence of parenting coordination's effectiveness, Family Court Review, 56(1).

In response to the increasing use of parenting coordination by mental health professionals and lawyers, the Association of Family and Conciliation Courts (AFCC) published Guidelines for Parenting Coordination in 2006 and the American Psychological Association (APA) published Guidelines for the Practice of Parenting Coordination in 2012 (APA, 2012). In the United States, more than half of the states have statutes or court rules authorizing the appointment of a parenting coordinator. While these guidelines were developed in response to the increasing practice of parenting coordination, jurisdictions with laws, statutes, or court rules varied in their definition of the role and scope of authority, including whether or not decisionmaking was a function of parenting coordination. In addition, training requirements vary by jurisdiction, although many of the states that have authorized the use of parenting coordination since 2006 have relied on the AFCC Guidelines in developing their statute or role, and their training requirements.

To our knowledge, internationally, parenting coordination is being practiced in Canada, with a statute in British Columbia and with consent in Ontario; Sweden since the first author conducted trainings based on the AFCC guidelines beginning in 2009 (Fieldstone, Carter, King, \& McHale, 2011); Italy, with trainings conducted by Debra Carter in 2014 (Piccinelli, Mazzoni, \& Carter, 2014); Singapore in 2015 and 2017 by Debra Carter (Ng, personal communication, September 9, 2017); and recently in Hong Kong (Sullivan, personal communication, October 30, 2014). Given the small network of parenting coordinators, paucity of published papers on PC, and the absence of an international database, it is difficult to determine the scope of the practice in other countries. 
Cite as: $\quad$ Deutsch, M.R., Misca, G. and Ajoku, C. (2018) Critical review of research evidence of parenting coordination's effectiveness, Family Court Review, 56(1).

In 2014, the American Psychological Association published a book (Higuchi \& Lally, 2014) which brought together the available knowledge around the theory and practice of parenting coordination, grounded in the APA and AFCC practice guidelines and summarized with chapters authored by "authors who are at the forefront of parenting coordination practice, training, publication, and research" (Higuchi \& Lally, 2014, p. 5. ${ }^{1}$ The book includes foundational information about the practice of parenting coordination, as well as the available research, efficacy, and future of parenting coordination. This handbook is an effort to build a theoretical base for the practice of parenting coordination that can be shared with new and experienced parenting coordinators, with the expectation that the practice can be studied and taught in workshops, trainings, and graduate classes of law and mental health disciplines.

\begin{abstract}
AIMS
While the practice of parenting coordination has grown and developed over the past two decades, there is also a growth in published papers and empirical research on the practice itself (how it is practiced) and the effectiveness of parenting coordination.

This review aims to systematically assess the current state of available empirical research on parenting coordination effectiveness. To achieve this, the review will identify, classify, critically analyze and synthesize the existing research on parenting coordination, formulate conclusions about the evidence for its effectiveness, and identify gaps and areas where further research is needed.
\end{abstract}

\footnotetext{
${ }^{1}$ Authors include Debra Carter, Linda Delaney, Robin Deutsch, Giselle Hass, Shirley Higuchi, Jennifer Joyner-Hall, Joan Kelly, Margaret McKinney, Alan Nessman, Matthew Sullivan.
} 
Cite as: $\quad$ Deutsch, M.R., Misca, G. and Ajoku, C. (2018) Critical review of research evidence of parenting coordination's effectiveness, Family Court Review, 56(1).

\section{METHOD}

Literature searches of Google Scholar, PsycINFO, EBSCOHOST, ProQuest, and Web of Science databases from 2000 to 2017 were performed. The search strategy included key words: (Parenting AND Coordination); (Parent Coordinator); (parent* AND coordinat*). Further handsearches were then conducted by scanning the bibliographies of the selected papers for other relevant articles. Also, searches were performed on papers that cited the studies. Initial searches retrieved relevant articles, book chapters, dissertations, and guidelines involving parenting coordination.

Studies were included in the review sample if: 1) they reported data on parenting coordinators or coordination; 2) were based on empirical data; and 3) were peer-reviewed and reported in English. A quality appraisal of the studies was undertaken independently by the first two authors (RD and GM) (with disagreement resolved via discussion) on criteria including study design, sample size and representativeness, outcome measures, and statistical power of results, as applicable.

A total of 13 studies satisfied the inclusion criteria. Of these, three studies were unpublished reports of which two were dissertations (one doctoral and one master's). Given the scarcity of the research on the topic and following quality appraisal the decision was made to include these three studies in the current review. A potential bias identified refers to the outlet of the published studies: the majority of the published studies ( 8 out of 10) were published in the Family Court Review, which is the AFCC's journal. The remaining two studies were both published in the Journal of Child Custody.

The studies identified in the review broadly centered on three main themes: 1) studies of parenting coordinator's perceptions of their role and function (4 studies); 2) studies exploring 
Cite as: $\quad$ Deutsch, M.R., Misca, G. and Ajoku, C. (2018) Critical review of research evidence of parenting coordination's effectiveness, Family Court Review, 56(1).

professionals' and parents' views and perceptions of parenting coordination (6 studies); and 3) studies examining outcomes of parenting coordination, including some measures of the effectiveness of the PC process ( 3 studies). The analysis was facilitated by tabulation of studies grouped by these 3 themes as summarized in Table 1. Given the extensive heterogeneity of studies in terms of samples, design, and outcome measures employed (which precluded the use of meta-analysis) a narrative synthesis was employed as the most appropriate method of analysis.

\section{DISCUSSION OF THE REVIEW FINDING}

Although a number of articles identified discussed the components involved in the practice of parenting coordination, only a few empirical articles covered the effectiveness of parenting coordination as perceived by parenting coordinators and outcomes associated with parenting coordination. Generally, the empirical studies have also collected data pertaining to demographics, training, and background of parenting coordinators. Thus, the analysis is presented around these three main themes.

\section{THEME 1. PERCEPTIONS OF PARENTING COORDINATORS' ROLE}

Kirkland and Sullivan (2008) surveyed a group of 54 AFCC member parenting coordinators to gather information about how parenting coordination is performed, as well as information related to board/bar complaints, civil lawsuits, and ethical issues. The survey participants were mental health professionals and attorneys who had practiced, on average, eight years as a parenting coordinator. The survey contained 20 questions addressing the basis of authority (court order, court order and consent, or private PC agreement), fees, lawsuits and board/bar complaints, and malpractice insurance. 
Respondents agreed that parenting coordination is thought to be effective because the parenting coordinators are readily available to their clients, possess pertinent legal and psychological knowledge/training that allows parenting coordinators to address the particular needs of their clients, and provide an alternative dispute resolution framework through which high-conflict parents can effectively address issues related to their role.

Beck, Putterman, Sbarra, and Mehl (2008) conducted an exploratory study and interviewed, in Pima County Arizona, 11 parenting coordinators from diverse backgrounds including doctoral level psychologists, lawyers, joint degrees and master's level mental health professionals, divided fairly equally by gender. The interviews consisted of seven questions that were then classified into emergent themes. Of interest was that almost one third of the parenting coordinators never met face-to face with their clients. They tended to use mostly a mediation model of intervention and saw their role as an authority figure first and facilitator/educator second. Their goals were efficiency of the system first and facilitative/educative second. An important finding in this study was that the attorney parenting coordinators carried the majority of the parenting coordinator cases, as compared to the mental health professionals. Authors speculated this might explain the use of mediation ${ }^{2}$ as the primary intervention model. Due to the low reimbursement for parenting coordination services in this county, the PCs use written communications to reduce costs. Limitations of the study include the very small sample in one county, which cannot be generalized, as well as the absence of standardized measures.

Hayes (2010) interviewed 14 parenting coordinators, in North Carolina, regarding their practices and procedures (similar to the survey done by Kirkland \& Sullivan, 2008) and then

\footnotetext{
${ }^{2}$ The term mediation is usually used by parenting coordinators and in the parenting coordinator guidelines, though the confidentiality that typically accompanies mediation is not present in parenting coordination.
} 
asked participants to respond to five case-based vignettes containing ethical and legal dilemmas. The parenting coordinators were from legal and mental health disciplines and had been practicing on average for 3.5 years. Results found that the three major roles of the parenting coordination process - plan implementation, plan compliance, and resolving issues in a timely manner - were supported by these parenting coordinators. They also used strategies related to published parenting coordinator functions, but tended to combine assessment and case management into a single function and created an enforcement function distinct from any other function, that they considered their primary function. The mediation function of the parenting coordinator and the nature of this role as an ADR process were reinforced in this study. Hayes, Grady, and Brantley (2012) surveyed 51 parenting coordinators from 19 states and two Canadian provinces who responded to a request to the AFCC parenting coordination Yahoo group and several other list-serves and discussion groups. Approximately two-thirds of the respondents were mental health professionals, and almost one-third held a Juris Doctor degree, with 5\% holding dual degrees. The online survey included 42 questions. Some of the results suggest that over half of respondents report email was most effective as the method of communication and that the majority of the parenting coordinators sought input from mental health professionals, lawyers, and the children. Parenting coordinators also reported that one-half of their cases return to court occasionally or never since their involvement and most did not go to court over their decisions. Parenting coordinators also indicated that the presence of a parent with a severe personality disorder or failure to pay were the most significant issues that may affect the PC's effectiveness. Most respondents agreed their role should be educational and that they should mediate issues first. Two-thirds agreed their primary role should be enforcement. Three-quarters of the parenting coordinators agreed that arbitration was necessary and $86 \%$ felt 
Cite as: $\quad$ Deutsch, M.R., Misca, G. and Ajoku, C. (2018) Critical review of research evidence of parenting coordination's effectiveness, Family Court Review, 56(1).

the parenting coordinator should have mental health training. This exploratory study was based on a relatively small sample taken primarily from AFCC members and has limited generalizability but does provide a basis for future research into parenting coordination practices looking at differences by discipline and training.

\section{THEME 2: EFFECTIVENESS OF PARENTING COORDINATION: PROFESSIONALS' AND PARENTS' VIEWS}

Armbruster (2011) used survey data obtained from AFCC parenting coordinators to explore specific factors that parenting coordinators identified as necessary for their successful practice as well as factors that impede successful parenting coordination. The results of the study identified the core theme as the efficacy predictors for parenting coordination with the six subthemes identified as: reduction in professional liability for PCs, burnout, uniformity and standardization, professional training and academic readiness, lack of support, and parenting coordination process.

The study indicates that PCs feel that there is a lack of support that hinders a PC's ability to carry out their duties efficiently and effectively. Furthermore, this lack of support is a thread that runs through all six of the subcategories under the efficacy theory of parenting coordination. In order for parenting coordination to be successful, support must exist throughout the process and at multiple levels (court system, licensing board, support from other professionals, support from lawyers, etc.).

A strength of the study is that it attempts to explore not only how parenting coordination is performed but also the factors involved in fostering or hindering the success of parenting coordination. However, the study employed a small convenience sample (first 10 participants 
who responded to request for participation and met study requirements) and did not represent a diverse group of PC practitioners, (from only six different states: Indiana, Massachusetts, Montana, Minnesota, Pennsylvania, and Texas). This limits significantly the generalizability of the survey data.

Fieldstone, Carter, King, and McHale (2011) used survey data collected from parenting coordinators in Florida, exploring their perceptions of the effectiveness of parenting coordination. The results indicate that, in general, parenting coordinators believe that their work is successful as measured by the respondents' perceptions of what percentage of their PC cases had met case goals. For example, the majority of respondents estimated that $60-80 \%$ of their cases had met case goals. When cases did not meet goals, and were thus unsuccessful, the top factors identified by PCs were client factors, lack of support from the court system, and interference in the process by third-parties (e.g., attorneys). Regarding potentially successful interventions, PCs were most likely to use psychoeducation, helping parents resolve contentious issues, teaching clients about "win-win" agreements, teaching co-parents to approach the coparent relationship as they would a relationship with a co-worker, facilitating parenting plan changes, teaching good email skills, and being in contact with one or both attorneys. Additionally, this study highlighted the importance of the role of the PC as an educator.

The PC respondents in this study had varied experience and educational background thus increasing the likelihood that the results reflect the perceptions of PCs regardless of their professional backgrounds. The small sample size of respondents, limited to PCs in Florida (67 PCs in Florida - 207 were contacted with $32 \%$ responding), makes it difficult to ascertain if the results accurately reflect the broader PC population and therefore whether the results and conclusions drawn are a valid and reliable reflection of perceptions of the practice and 
effectiveness of parenting coordination amongst PCs. Although successful cases were identified as those in which case goals were met, the study does not define what it means to meet case goals and thus, it is conceivable that there were variations in the ways in which different participants defined meeting case goals.

Fieldstone, Lee, Baker, and McHale (2012) further explored perceptions of the effectiveness of parenting coordination by surveying PCs and also family law attorneys and judges regarding their expectations, opinions, and perceived effectiveness of parenting coordination. The results of this study indicate that, in general, attorneys and judges believe that a parenting coordination statute would increase the likelihood of using a parenting coordinator. The findings indicate that attorneys' views about parenting coordination positively increase when they are more knowledgeable about parenting coordination and are linked to their perception of parenting coordinators as responsive. In addition, attorneys looked favorably on parenting coordination when the process improved the attorneys' relationships with their clients.

The results also indicate that judges, attorneys, and PCs believe the PC process works more effectively when both parties willingly agree to receive PC services. Data also indicates that of the three respondent groups, PCs are the group most likely to assess safety issues/concerns, and judges and attorneys differ with respect to their expectation regarding the modification of parenting plans. The data also indicates that all three survey participant groups differ with regard to expectations regarding payment/non-payment for PC services, with judges and attorneys believing the process can be cost prohibitive and judges inconsistently enforcing payment for PC services

Collectively, these findings suggest positive views regarding parenting coordination practice, however, this may also be due to participant selection bias. Moreover, the findings are 
Cite as: $\quad$ Deutsch, M.R., Misca, G. and Ajoku, C. (2018) Critical review of research evidence of parenting coordination's effectiveness, Family Court Review, 56(1).

unlikely to be representative and generalizable as the samples employed were small and limited geographically.

Belcher-Timme, Shorey, Belcher-Timme, and Gibbings (2013) explored which interventions parenting coordinators perceived as being most effective. The participants (79 PCs) were recruited via an AFCC list-serve. The survey assessed interventions into three categories: Assessment and Conceptualization; Education and Intervention; and Case and Conflict Management. Assessment and Conceptualization included four interventions: reviewing professional evaluations (psychological, custody, and others), identifying the parenting strengths and weaknesses of individual parents, assessing general co-parenting skills, and consideration of functioning and needs of children involved. Education and Information included three interventions: informing parents about the developmental needs of their children, teaching effective communication skills for parents (active listening, perspective taking, etc.), and providing information on the effects of high parental conflict on children. Case and Conflict Management included four interventions: communicating with other family members/caretakers, communicating with other professionals (schools, therapists, physicians, etc.), interpreting court orders, custody agreements, and other legal documents, and facilitating communication as an objective third-party.

Regarding interventions that fall under Assessment and Conceptualization, participants found three of the four interventions (identifying the parenting strengths and weaknesses of individual parents, assessing general co-parenting skills, and consideration of functioning and needs of children involved) to be equally effective. Participants, however, found "reviewing professional evaluations" to be a less effective intervention than the other three. 
Cite as: $\quad$ Deutsch, M.R., Misca, G. and Ajoku, C. (2018) Critical review of research evidence of parenting coordination's effectiveness, Family Court Review, 56(1).

In terms of Education and Information based interventions, participants rated all three interventions (informing parents about the developmental needs of their children, teaching effective communication skills for parents, and providing information on the effects of high parental conflict on children) relatively equally and rated the interventions as being generally effective.

Regarding Case and Conflict Management interventions, participants perceived the four interventions as differing in their effectiveness. Participants identified facilitating communication as an objective third-party as the most effective of the four interventions, followed by interpreting court orders, custody agreements, and other legal documents, then communicating with other professionals. Finally, communicating with other family members/caretakers was determined to be less effective than the other three interventions.

Mandarino, Kline Pruett, and Fieldstone (2016) conducted a survey of 60 high conflict separated or divorced parents from the United States and Canada to learn more about their personality characteristics and to hear what they found to be most and least helpful about parenting coordination and other interventions. Of the 60 parents, 37 were involved with parenting coordination currently or within the last five years. Only one of the parents in a coparent dyad responded to and was included in the survey. The survey included demographic information as well as standardized measures of narcissism (Narcissistic Personality Inventory16), empathy (Toronto Empathy Questionnaire), conflict (Acrimony Scale), and a co-parenting style scale (developed by the first author). Parents who engaged in parenting coordination reported they learned useful skills (30\%) and focused on the child's best interests $(26 \%)$. Twenty-two percent (22\%) were satisfied with the knowledge and experience of their parenting coordinator and their neutrality (13\%). Parents were dissatisfied by lack of efficiency (27\%), 
lack of a working alliance (13\%), and 20\% felt their practitioner was unprofessional or unqualified. Specific to parenting coordination, themes of satisfaction with the intervention included logistical issues, interpersonal issues, case management, and level of authority. No more than $28 \%$ identified satisfaction with these themes. Parents were also satisfied with the PCs fairness and changed parent's thinking to recognize the best interests of the child. Four themes of dissatisfaction with the intervention included lack of authority (30\%), cost (10\%), lack of working alliance, and timing (7\% each). Themes of Dissatisfaction included the PCs perceived as biased toward the other parent (37\%), unqualified (33\%), and unprofessional (27\%). Parents were equally split between feeling very dissatisfied, neutral, or very satisfied with the parenting coordination experience. Regarding their experience with their parenting coordinator they were either very satisfied or very dissatisfied and were either very likely or very unlikely to recommend parenting coordination to others. Two other themes included attributing a lack of success to the other parent and not feeling heard or validated. Regarding the personality scores of these parents, in the combined group those using parenting coordination were not separated, however participants scored low on narcissism, high on empathy, and either conflicted or parallel in co-parenting.

Limitations of the study are that data come from just one of the co-parents who self selected to participate. It is unclear whether these participants agreed to participate because they had strong feelings about the interventions they used, thus making it difficult to generalize to a larger population. The self-report measures were completed by one of a co-parent dyad and therefore may not reflect an objective view of the co-parenting relationship. The results also reflect a mix of parents involved in parenting coordination, other ADR or therapeutic 
Cite as: $\quad$ Deutsch, M.R., Misca, G. and Ajoku, C. (2018) Critical review of research evidence of parenting coordination's effectiveness, Family Court Review, 56(1).

interventions, thus we cannot generalize to the population of parents who use parenting coordination.

Hirsch (2016) conducted a study as part of her Master of Science (MSc) thesis, interviewing seven mental health parenting coordinators (six psychologists and one social worker) with at least three years of experience to determine the practices parenting coordinators found to be effective and would recommend to others to educate parents, increase the quality of parenting, manage conflict, and involve children and other family members in the process. She recruited her subjects from a multidisciplinary family law listserv of legal and mental health professionals in the metropolitan Washington DC area including Maryland, DC, and Northern Virginia and from recommendations and referrals from the approximately 1000 members.

Hirsch (2016) conducted a face-to-face interview with each participant and conducted a semi-structured interview and demographics questionnaire. She analyzed the transcripts using open coding and thematic analysis with each transcript segmented into categories of information and grouped into themes. Though the sample is small and cannot be generalized, a number of practices used by mental health parenting coordinators to educate parents, improve the quality of parenting and co-parenting, manage conflict, and involve children and family members expands the recommended practices that can be used for training, peer support and future studies to create positive changes for the family.

In general, the studies outlined above indicate that parenting coordination is perceived as an effective tool in helping high conflict co-parents. This positive perception of parenting coordination is held not only by parenting coordinators, but by attorneys and judges as well, even though attorneys and judges differed slightly with regard to their expectations regarding the scope of the parenting coordinator's authority. Additionally, judges and attorneys looked more 
favorably upon the process when they knew more about it. The studies also indicate that in order for parenting coordination to be successful support must exist throughout the process and at multiple levels (court system, licensing board, support from other professionals, support from lawyers, etc.) in order to decrease burnout and increase a sense of support.

Some overarching limitations of the studies on perceptions of efficacy are that they have small convenience sample sizes, limited to one or a few jurisdictions (except for the Belcher et al. study), and that the results of the studies are often not generalizable. The studies also relied primarily on survey data. Additionally, definition of terms and identification of the discipline of the parenting coordinators was often vague or missing. It is difficult to generalize from these samples what disciplines use what interventions and find them effective, and whether attorneys and judges view all parenting coordinators the same. Finally, these studies did not look at the kinds of training the parenting coordinators who responded had and how that may have affected their perception of the role.

Parenting coordinators and other professionals were unified in their belief that they need training in mental health and law to be effective. While parenting coordinators tended to agree on the use of education, case management, and mediation and arbitration to help parents resolve their conflicts, judges were more likely to expect a parenting coordinator to modify or even create a parenting plan for the parents. In addition, practices varied by the discipline of the parenting coordinator, with attorney PCs more likely to see their primary job as enforcement, and mental health professionals used a variety of practices to educate and mange conflict between parents. 
Cite as: $\quad$ Deutsch, M.R., Misca, G. and Ajoku, C. (2018) Critical review of research evidence of parenting coordination's effectiveness, Family Court Review, 56(1).

\section{THEME 3. PARENTING COORDINATORS' EFFECTIVENESS: OUTCOME STUDIES}

A small number of studies go beyond assessing perceptions of parenting coordination as indicated and explore the effectiveness of parenting coordination by measuring outcomes of the PC intervention. For example, Henry, Fieldstone, and Bohac (2009) explore the extent to which participation in parenting coordination minimizes and/or eliminates relitigation between high conflict co-parenting partners by analyzing the extent to which the number of motions filed changed one year after high conflict co-parenting partners began utilizing parenting coordination. The study compared the total number of motions filed one year prior to (2005-2006) and one year following (2006-2007) the receipt of parenting coordination services.

The findings indicate a reduction of approximately $75 \%$ in child-related court filings and a $40 \%$ reduction with regard to other motions, resulting in a $50 \%$ reduction in all motions filed. Over $60 \%$ of the co-parenting pairs filed less motions within the first year of receiving parenting coordination services. Furthermore, the results indicate that parenting coordination is most effective in decreasing motions filed in cases with two to six years of prolonged litigation.

In general, the study indicates that parenting coordination seems to be effective in reducing the number of motions filed by high-conflict parents and is helpful to parents beyond child-related issues. Overall, parenting coordination seems to be an effective means of reducing court hearings and improving the ability of high-conflict parents to resolve their issues outside of the court system.

This study is significant as it attempts to objectively measure the effectiveness of parenting coordination by comparing the total number of motions filed one year prior to (20052006) and one year following (2006-2007) the receipt of parenting coordination services. However, the participants in the study were not randomly selected nor was a control group 
employed (e.g., dyads that did not receive PC services) and the research design limits the generalizability of the findings. Moreover, data were obtained from only one court system, thus, the participants may not be reflective of high conflict dyads, court mandated to parenting coordination, across the nation. In addition, the case study research design does not explore other potential variables that might explain the reduction in motions filed. The use of in-depth qualitative and/or quantitative data collection methods might have provided more insight into when, why, and how parenting coordination reduces motions filed.

Scott, Ballard, Sawyer, Ross, Burkhauser, Ericson, and Lilja (2010) examined the efficacy of parenting coordination by exploring the outcomes associated with the Parenting Coordination (PC) Program ${ }^{3}$ with regard to parental conflict, co-parenting, and behavioral outcomes for children. Lally \& Higuchi (2008) report on the first two-year pilot of this study. Overall, this study is significant as it includes some standardized measures on child outcomes and child-parent relationship outcomes.

Outcome data were collected from parents when they began the PC program and then again one or more times (at least 6 months) after enrollment. With regard to outcomes, the data indicate a statistically significant relationship between participation in the PC Program and a reduction in the burden on court resources. Pre and post-test results suggest a decrease in court activities, a decrease in the number of cases in which contempt was filed, a decrease in the percentage of cases in which a parent was found in contempt, and an increase in the number of cases in which resolution was found without a court order. However, with two exceptions, the

\footnotetext{
${ }^{3}$ In 2004, the Parenting Coordination (PC) Program was created in order to expand the use of PC services to populations that would ordinarily be unable to afford PC services (in this case, low income, high conflict, families involved in child custody disputes in D.C.). In 2009, APA requested that Child Trends analyze data from the PC Program and the Scott et al report is based on these data.
} 
Cite as: $\quad$ Deutsch, M.R., Misca, G. and Ajoku, C. (2018) Critical review of research evidence of parenting coordination's effectiveness, Family Court Review, 56(1).

findings related to parents' perceptions of their relationship with one another and their children's behavior, did not reach statistical significance, most likely due to due to the small sample size. The exceptions refer to fathers' reports of statistically significant levels of affective problems for children aged 6-18 both pre- and post-test, and their additional reports of statistically significant lower levels of post-traumatic stress problems for their children.

In summary, this outcomes study indicates that the PC Program had a positive impact on court outcomes and some positive impact on child behavior. Notably, this study employed objective measures of court and child outcomes. Nevertheless, the conclusions are limited because of the small sample size, lack of a control or comparison group, and participants' attrition at the post-test stage.

In a promising development, Brewster, Beck, Anderson, \& Benjamin (2011) have developed and piloted a research method for evaluations of PC programs. They investigated 21 new PC cases longitudinally over a period of 2 years (with baseline assessment prior to the assessment of a PC and follow-up stage after 2 years). Five percent of the participants dropped out of the PC process. The study's aim was two-fold: to investigate whether the parenting coordinator is potentially effective in: 1) easing the burden on the judges, court personnel, and outside agencies as well as 2) assisting the high-conflict families to reduce the number of motions and changes made in each case for a 2-year period. Although only a pilot study with a small sample, the preliminary results show promising evidence that a parenting coordinator assigned to the cases has the potential to significantly reduce the amount of resources that highconflict families demand from both court professionals and outside agencies.

In summary, although the number of studies addressing outcome measures associated with parenting coordination are limited, promising evidence is emerging suggesting that the 
parenting coordination process is effective from the point of view of courts, outside agencies, and families themselves. It is also essential to understand when and why the PC process is not always effective, for example, there are some issues that parenting coordination typically do not address (e.g., financial issues), and/or some characteristics of the parents involved (e.g., severe mental illness and/or personality disorders) that may not be a good fit for the parenting coordination process. Critically, more research needs to address the issue of effectiveness of PC by implementing objective, tried and tested measures of outcomes that allow comparability across samples.

\section{CONCLUSIONS}

This review of research evidence on the effectiveness of parenting coordination concludes with confidence that, although promising methodological approaches are underway, the research is limited by a small number of studies of variable quality, and none use a control group or experimental design(s). In addition the studies look mostly at the parenting coordinators' perceptions of their work. Therefore, confident conclusions cannot be drawn regarding the effectiveness of the $\mathrm{PC}$ process. Consequently, this review will propose directions that future research-underpinned theory development needs to focus on.

It can be argued that the PC development is still in its 'early years', however the fact that the review identified 10 research studies over the past decade dedicated to the effectiveness of parenting coordination is testimony to the growing interest in this process and its promise. Notably, eight of the ten published studies were published in the Family Court Review, two in the Journal of Child Custody, and two were unpublished dissertations. The publication outlet for the majority of the studies may suggest a potential bias through imbalance of reported findings. 
Despite some models of PC training based on AFCC and the APA guidelines, ${ }^{4}$ there is a distinct lack of any theoretical underpinning of the parenting coordination practice. It is thus imperative for professionals and researchers to collaborate towards the development of a unified theoretical model to inform the PC role, practice, and ultimately to allow objective assessment of its effectiveness. Theory-underpinned research will then need to be conducted with methodological rigor to understand how, when and with whom the PC practice is most effective and when it is not. A theoretical model will also allow the development and implementation of standardized training to ensure quality in the delivery of PC practice.

The current body of research indicates that the PC process is perceived as effective and produces quantifiable outcome measures. Additionally, by looking at specific interventions identified as effective or most effective, the studies provided insight into areas of training focus. At the same time, although the studies reviewed have provided insight into perceptions of the effectiveness of parenting coordination, as well as provided some objective outcome measures related to effectiveness, there still exists a lack of a research on perceptions of effectiveness and studies that measure objective outcome measures related to efficacy. Specifically, pre and post measures of parental conflict, co-parent effectiveness, the impact on the children's behavior, and the number of parenting-related disputes brought to court by families with a parenting coordinator, as compared to those without that service, need to be evaluated. In addition, the studies do not clearly differentiate the functions included in the role of the parenting coordinator. The PC role was developed to include limited decision-making authority. In some states, the PC role is diluted so that PCs are not allowed to make even minor decisions in child related disputes.

\footnotetext{
${ }^{4}$ We are aware of other training that preceded or is not based on the Guidelines, i.e., Susan Boyan and Ann Marie Termini (http://www.cooperativeparenting.com/index.html).
} 
Cite as: $\quad$ Deutsch, M.R., Misca, G. and Ajoku, C. (2018) Critical review of research evidence of parenting coordination's effectiveness, Family Court Review, 56(1).

It will be important for future research to clearly identify whether decision-making is part of the PC role, and whether that affects the number of child and parenting-related disputes filed in court.

While the current body of literature supports the notion that parenting coordination is a service best provided by those with mental health and legal backgrounds, or a combination of both, more studies must be conducted in order to explore what determines if the parenting coordination process has been effective and how one can objectively measure effectiveness. The parenting coordinator role is unique in that, like mediators, it is typically performed by multiple disciplines including psychologists, psychiatrists, social workers, mental health counselors, mediators, and attorneys. Research that looks at the differences in perceptions of role, application of knowledge base and training to functions, and effectiveness based on the discipline of the parenting coordinator would be useful as it applies to different kinds of family characteristics and problems. Differences in how practitioners from the different mental health and legal disciplines manage their cases using primarily judicial models, mediation models ${ }^{5}$, or other models of change and intervention were explored by Beck, Putterman Sbarra, \& Mehl (2008). Linking the intervention model to discipline and training of the parenting coordinator and type of family is a future area of research.

Efforts must also be made to include a larger sample of parenting coordinators/participants in studies from an array of jurisdictions. Finally, it would benefit the field of parenting coordination to begin to explore the characteristics of the families who make use of the parenting coordination practice as well as whether or not there are certain variables

\footnotetext{
${ }^{5}$ Parenting coordinator guidelines describe one of the functions as mediation. However, in most jurisdictions mediation is confidential but in the PC role, is not. It might behoove the field to refer to this function as something else, such as facilitative negotiation to clearly differentiate it from the typical mediation role.
} 
that make a family a good or poor candidate for the parenting coordination process and how to disseminate PC services so that it can reach those who could benefit from this intervention. For example, preliminary evidence from the perspective of the parenting coordinators seem to indicate that this intervention is not suited for parents with severe personality disorders (Hayes, 2012). Another factor to consider may include the commitment of the parents to the PC process. Carter and Lally (2014) suggest that the second generation of research on the efficacy of parenting coordination programs begin with a research group of participants who could propose the common information to be gathered in a standardized format. Ideally, in the future, they advocate for a third generation of studies to evaluate PC programs and use comparison groups and random assignment to evaluate whether the goals were met and change is in fact due to the parenting coordination intervention. Variables such as PC discipline and training may be included in these studies. In addition future research should consider the population of people for whom parenting coordination is most likely to work by considering the personality functioning of the participants, the dynamics of the co-parent relationship, and their commitment to the PC process.

\section{REFERENCES}

AFCC Task Force on Parenting Coordination (2005). Guidelines for parenting coordination. Family Court Review, 44(1), 162-181. Retrieved from https://www.afccnet.org/Portals/0/PublicDocuments/Guidelines/AFCCGuidelinesforParentingc oordinationnew.pdf

American Psychological Association (2012). Guidelines for the practice of parenting coordination. American Psychologist, 67(1), 63-71. doi: 10.1037/a0024646 
Cite as: $\quad$ Deutsch, M.R., Misca, G. and Ajoku, C. (2018) Critical review of research evidence of parenting coordination's effectiveness, Family Court Review, 56(1).

Armbruster, K. M. (2011). An exploration of parenting coordination as a form of alternative dispute resolution with high conflict parents: A qualitative study (Unpublished Doctoral Dissertation). Capella University, Minnesota.

Baris, M. A., Coates, C. A., Duvall, B. B., Garrity, C. B., Johnston, E. T., \& LaCrosse, E. R. (2001). Working with high-conflict families of divorce: a guide for practitioners. Northvale, NJ: Jason Aronson Publishers.

Beck, C. J., Putterman, M. D., Sbarra, D. A., \& Mehl, M. R. (2008). Parenting coordinator roles, program goals and services provided: Insights from the Pima County, Arizona program. Journal of Child Custody, 5(1-2), 122-139.

Belcher-Timme, R. O., Shorey, H. S., Belcher-Timme, Z. B., \& Gibbings, E. N. (2013). Exploring best practices in parenting coordination: A national survey of current practices and practitioners. Family Court Review, 51(4), 651-665.

Brewster, K. O. H., Beck, C. J., Anderson, E. R., \& Benjamin, G. A. H. (2011). Evaluating parenting coordination programs: Encouraging results from pilot testing a research methodology. Journal of Child Custody, 8(4), 247-267.

Carter, D. K., \& Lally, S. L. (2014). Charting the challenging path toward establishment of parenting coordination's efficacy. In S. A. Higuchi \& S. L. Lally, (Eds.), Parenting Coordination in Postseparation Disputes, (pp. 241-263). Washington, DC: American Psychological Association.

Coates, C., Deutsch, R., Starnes, H., Sullivan, M. J., \& Sydlik, B. (2004). Parenting coordination for high conflict families. Family Court Review, 42(2), 246-262.

Fieldstone, L., Carter, D. K., King, T., \& McHale, J. P. (2011). Training, skills, and practices of parenting coordinators: Florida statewide study. Family Court Review, 49(4), 801-817. 
Cite as: $\quad$ Deutsch, M.R., Misca, G. and Ajoku, C. (2018) Critical review of research evidence of parenting coordination's effectiveness, Family Court Review, 56(1).

Fieldstone, L., Lee, M. C., Baker, J. K., \& McHale, J. P. (2012). Perspectives on parenting coordination: Views of parenting coordinators, attorneys, and judiciary members. Family Court Review, 50(3), 441-454.

Hayes, S. W. (2010). More of a street cop than a detective: An analysis of the roles and functions of parenting coordinators in North Carolina. Family Court Review, 48(4), 698-709.

Hayes, S., Grady, M., \& Brantley, H. T. (2012). E- mails, statutes, and personality disorders: A contextual examination of the processes, interventions, and perspectives of parenting coordinators. Family Court Review, 50(3), 429-440.

Henry, W. J., Fieldstone, L., \& Bohac, K. (2009). Parenting coordination and court relitigation: A case study. Family Court Review, 47(4), 682-697.

Higuchi, S. A., \& Lally, S. L. (Eds.). (2014). Parenting coordination in postseparation disputes, Washington, DC: American Psychological Association.

Hirsch, B. P. (2016). Parenting coordinators' practices recommendations: A qualitative study (Unpublished masters of science dissertation). Virginia Polytechnic Institute and State University, Virginia.

Kirkland, K., \& Sullivan, M. (2008). Parenting coordination (PC) practice: A survey of experienced professional. Family Court Review, 46(4), 622-636.

Lally, S. J., \& Higuchi, S. A. (2008). The American Psychological Association parenting coordination project: Development of the project and initial review of the first two years. Journal of Child Custody, 5(1-2), 101-121. doi:10.1080/15379410802070435 
Cite as: $\quad$ Deutsch, M.R., Misca, G. and Ajoku, C. (2018) Critical review of research evidence of parenting coordination's effectiveness, Family Court Review, 56(1).

Mandarino, K., Kline Pruett, M., \& Fieldstone, L. (2016). Co- parenting in a highly conflicted separation/divorce: Learning about parents and their experiences of parenting coordination, legal, and mental health interventions. Family Court Review, 54(4), 564-577.

Piccinelli, C., Mazzoni, S., Carter, D. (2014). La coordinazione genitoriale, dagli USA un nuovo intervento di supporto per le coppie in separazione/divorzio ad elevata conflittualità cronica. Diritto della Famiglia e dei Minori, 2, 1-21. Retrieved from http://www.ilcaso.it/articoli/768.pdf

Scott, M., Ballard, F., Sawyer, C., Ross, T., Burkhauser, M., Ericson, S., \& Lilja, E. (2010). The Parenting Coordination (PC) Project implementation and outcomes study report. Washington, DC: Child Trends, American Psychological Association. 
Cite as: $\quad$ Deutsch, M.R., Misca, G. and Ajoku, C. (2018) Critical review of research

evidence of parenting coordination's effectiveness, Family Court Review, 56(1).

\section{THE AUTHORS}

Robin Deutsch, Ph.D., ABPP, is the director of the Center of Excellence for Children, Families and the Law at William James College (www.williamjames.edu/cffc). Previously she was on the faculty of Harvard Medical School, most recently as an associate clinical professor of psychology. She is a child and family forensic psychologist, mediator, and parenting coordinator and is board certified in couple and family psychology. She developed and currently teaches the Certificate in Child and Family Forensic Issues at William James College and is a founder of Overcoming Barriers, an organization that provides family-centered services for families in conflict. She is a past president of the Association of Family and Conciliation Courts and former chair of the American Psychological Association Ethics Committee. She is the coauthor of 7 Things Your Teenager Won't Tell You: and How to Talk about Them Anyway (Ballantine, 2005, 2011) and coeditor of the book Overcoming Parent-Child Contact Problems: Family-Based Interventions for Resistance, Rejection, Alienation (Oxford, 2016).

Gabriela Misca, Ph.D., CPsychol, CSci, AFBPsS, FHEA, is a British psychologist and faculty member at the University of Worcester, UK. She has researched, taught, and published widely on the topic of family diversity and child development and mental health, with her research addressing interdisciplinary issues of children growing up in complex and/or adverse family circumstances. Recently her research has encompassed issues related to military veterans and their families; she held a 2015-16 Fulbright fellowship at William James College where she researched best practices in supporting military families in the United States and assessing their cultural transferability.

Chioma Ajoku, J.D., Ph.D., is a Family Court Mental Health Services psychologist with the Family Court Clinic department of New York City Health1Hospitals. She performs a variety of courtordered forensic evaluations. Prior to this work, she was a child and family forensic postdoctoral fellow at William James College where she provided forensic evaluation and consultation services to courts, attorneys, and public and private agencies on issues for which children and families were involved in the legal system. During her fellowship year, she also received a certificate in child and family forensic issues. 
Cite as: $\quad$ Deutsch, M.R., Misca, G. and Ajoku, C. (2018) Critical review of research evidence of parenting coordination's effectiveness, Family Court Review, 56(1).

Table 1. Summary of studies included in the review

\begin{tabular}{|c|c|c|c|c|c|c|}
\hline & Study (authors, year) & Participants & Study design & Measures $^{i}$ & Main findings & Limitations \\
\hline & EME 1. PERCEPTIONS OF PA & NTING COORD & ' ROLE & & & \\
\hline 1 & $\begin{array}{l}\text { Beck, C. J., Putterman, M. } \\
\text { D., Sbarra, D. A., \& Mehl, } \\
\text { M. R. (2008). Parenting } \\
\text { coordinator roles, program } \\
\text { goals and services } \\
\text { provided: Insights from the } \\
\text { Pima County, Arizona } \\
\text { program. Journal of Child } \\
\text { Custody, 5(1-2), 122-139. }\end{array}$ & $\begin{array}{l}\mathrm{N}=11 \mathrm{PCs} \\
\text { (working with } \\
20 \text { families) } \\
\text { listed on the } \\
\mathrm{PC} \text { roster in } \\
\text { the Pima } \\
\text { County, } \\
\text { Arizona. }\end{array}$ & $\begin{array}{l}\text { Cross-sectional } \\
\text { qualitative }\end{array}$ & $\begin{array}{l}\text { Interviews } \\
7 \text { questions } \\
\text { classified into } \\
\text { emergent themes }\end{array}$ & $\begin{array}{l}\text { Almost one third of the PCs } \\
\text { never met face-to face with } \\
\text { their clients; } \\
\text { PCs used mostly a mediation } \\
\text { model of intervention; } \\
\text { PC saw their role as an } \\
\text { authority figure first and } \\
\text { facilitator/educator second. } \\
\text { Attorney PCs carried the } \\
\text { majority of the PC cases } \\
\text { compared to the mental health } \\
\text { professionals. }\end{array}$ & $\begin{array}{l}\text { Small sample from } \\
\text { county which } \\
\text { cannot be } \\
\text { generalized } \\
\text { The absence of } \\
\text { standardized } \\
\text { measures. }\end{array}$ \\
\hline 2 & $\begin{array}{l}\text { Hayes, S. W. (2010). "More } \\
\text { of a street cop than a } \\
\text { detective": An analysis of } \\
\text { the roles and functions of } \\
\text { parenting coordinators in } \\
\text { North Carolina. Family } \\
\text { Court Review, 48(4), 698- } \\
709 .\end{array}$ & $\begin{array}{l}\mathrm{N}=14 \\
\text { parenting } \\
\text { coordinators in } \\
\text { North Carolina }\end{array}$ & $\begin{array}{l}\text { Cross-sectional } \\
\text { qualitative }\end{array}$ & $\begin{array}{l}\text { Interviews + used } \\
\text { five case-based } \\
\text { vignettes } \\
\text { containing ethical } \\
\text { and legal } \\
\text { dilemmas }\end{array}$ & $\begin{array}{l}\text { PCs were from legal and } \\
\text { mental health disciplines and } \\
\text { had been practicing on average } \\
\text { for } 3.5 \text { years } \\
3 \text { major roles of the PCs were: } \\
\text { plan implementation, plan } \\
\text { compliance, and resolving } \\
\text { issues in a timely manner }\end{array}$ & $\begin{array}{l}\text { Small sample } \\
\text { limited } \\
\text { geographically } \\
\text { thus no } \\
\text { generalizability. }\end{array}$ \\
\hline 3 & $\begin{array}{l}\text { Hayes, S., Grady, M., \& } \\
\text { Brantley, H. T. (2012). E- } \\
\text { mails, statutes, and } \\
\text { personality disorders: a } \\
\text { contextual examination of } \\
\text { the processes, } \\
\text { interventions, and } \\
\text { perspectives of parenting }\end{array}$ & $\begin{array}{l}\mathrm{N}=51 \\
\text { parenting } \\
\text { coordinators } \\
\text { from } 19 \text { states } \\
\text { and two } \\
\text { Canadian } \\
\text { provinces } \\
\text { recruited via }\end{array}$ & $\begin{array}{l}\text { Cross-sectional } \\
\text { quantitative }\end{array}$ & $\begin{array}{l}\text { online survey } \\
\text { with } 42 \text { questions }\end{array}$ & $\begin{array}{l}\text { Over half of respondents } \\
\text { report email was most } \\
\text { effective as the method of } \\
\text { communication; } \\
\text { Majority of the PCs sought } \\
\text { input from mental health } \\
\text { professionals, lawyers, and the } \\
\text { children }\end{array}$ & $\begin{array}{l}\text { Small sample } \\
\text { taken primarily } \\
\text { from AFCC } \\
\text { members and has } \\
\text { limited } \\
\text { generalizability. }\end{array}$ \\
\hline
\end{tabular}


Cite as: $\quad$ Deutsch, M.R., Misca, G. and Ajoku, C. (2018) Critical review of research evidence of parenting coordination's effectiveness, Family Court Review, 56(1).

\begin{tabular}{|c|c|c|c|c|c|c|}
\hline & Study (authors, year) & Participants & Study design & Measures $^{i}$ & Main findings & Limitations \\
\hline & $\begin{array}{l}\text { coordinators. Family Court } \\
\text { Review, 50(3), 429-440. }\end{array}$ & $\begin{array}{l}\text { the AFCC } \\
\text { parenting } \\
\text { coordination } \\
\text { yahoo group } \\
\text { and several } \\
\text { other list- } \\
\text { serves and } \\
\text { discussion } \\
\text { groups. }\end{array}$ & & & $\begin{array}{l}\text { Reportedly the presence of a } \\
\text { parent with a severe } \\
\text { personality disorder or failure } \\
\text { to pay were the most } \\
\text { significant issues that may } \\
\text { affect the PC effectiveness } \\
\text { Two thirds of PCs agreed their } \\
\text { primary role should be } \\
\text { enforcement }\end{array}$ & \\
\hline 4 & $\begin{array}{l}\text { Kirkland, K., \& Sullivan, M. } \\
\text { (2008). Parenting } \\
\text { coordination (PC) practice: } \\
\text { A survey of experienced } \\
\text { professional. Family Court } \\
\text { Review, } 46 \text { (4), 622-636. }\end{array}$ & $\begin{array}{l}\mathrm{N}=54 \text { of } 100 \\
\text { identified } \\
\text { AFCC PCs } \\
\text { comprising } \\
\text { psychologists, } \\
\text { MSW, LPCs } \\
\text { counsellors, } \\
\text { B.A. level PCS, } \\
\text { and attorneys. } \\
\text { On average, } \\
\text { the } \\
\text { participants } \\
\text { had practiced } \\
\text { as PCs for } 8 \\
\text { years. }\end{array}$ & $\begin{array}{l}\text { Cross-sectional } \\
\text { survey }\end{array}$ & $\begin{array}{l}20 \text { questions } \\
\text { addressing basis } \\
\text { of employment } \\
\text { (court order only, } \\
\text { court order of } \\
\text { mutual consent, } \\
\text { or use of a PC } \\
\text { written } \\
\text { agreement), fees, } \\
\text { lawsuits and } \\
\text { board/bar } \\
\text { complaints, and } \\
\text { malpractice } \\
\text { insurance. }\end{array}$ & $\begin{array}{l}\text { PC is performed by } \\
\text { experienced professionals } \\
\text { from legal and mental health } \\
\text { backgrounds and executed by } \\
\text { court order. } \\
\text { PC is thought to be effective } \\
\text { because parent coordinators } \\
\text { are readily available to their } \\
\text { clients, possess pertinent legal } \\
\text { and psychological knowledge / } \\
\text { training. }\end{array}$ & $\begin{array}{l}\text { Small sample size } \\
\text { thus lack of } \\
\text { generalizability }\end{array}$ \\
\hline \multicolumn{7}{|c|}{ THEME 2. EFFECTIVENESS OF PARENTING COORDINATION: PROFESSIONALS' AND PARENTS' VIEWS } \\
\hline 5 & $\begin{array}{l}\text { Armbruster, K.M. (2011). } \\
\text { An exploration of } \\
\text { parenting coordination as } \\
\text { a form of alternative } \\
\text { dispute resolution with } \\
\text { high conflict parents: A }\end{array}$ & $\begin{array}{l}\mathrm{N}=10 \\
\text { members of } \\
\text { AFCC (using } \\
\text { the parent } \\
\text { coordinator } \\
\text { list serve) had }\end{array}$ & $\begin{array}{l}\text { Cross-sectional } \\
\text { qualitative }\end{array}$ & $\begin{array}{l}\text { Semi-structured } \\
\text { telephone } \\
\text { interviews. }\end{array}$ & $\begin{array}{l}\text { PCs feel that there is a lack of } \\
\text { support that hinders their } \\
\text { ability to carry out their duties. } \\
\text { Support must exist throughout } \\
\text { the process and at multiple } \\
\text { levels (court system, licensing }\end{array}$ & $\begin{array}{l}\text { Small convenience } \\
\text { sample which did } \\
\text { not represent a } \\
\text { diverse group of } \\
\text { PC practitioners, } \\
\text { representing only }\end{array}$ \\
\hline
\end{tabular}


Cite as: $\quad$ Deutsch, M.R., Misca, G. and Ajoku, C. (2018) Critical review of research evidence of parenting coordination's effectiveness, Family Court Review, 56(1).

\begin{tabular}{|c|c|c|c|c|c|c|}
\hline & Study (authors, year) & Participants & Study design & Measures $^{i}$ & Main findings & Limitations \\
\hline & $\begin{array}{l}\text { qualitative study (Doctoral } \\
\text { Dissertation). }\end{array}$ & $\begin{array}{l}\text { been working } \\
\text { as a PC for at } \\
\text { least one year } \\
\text { and on at least } \\
\text { five parenting } \\
\text { coordination } \\
\text { cases }\end{array}$ & & & $\begin{array}{l}\text { board, other professionals, } \\
\text { lawyers, etc.). }\end{array}$ & $\begin{array}{l}\text { six states (Indiana, } \\
\text { Massachusetts, } \\
\text { Montana, } \\
\text { Minnesota, } \\
\text { Pennsylvania, and } \\
\text { Texas. }\end{array}$ \\
\hline 6 & $\begin{array}{l}\text { Belcher-Timme, R.O., } \\
\text { Shorey, H.S., Belcher- } \\
\text { TImme, Z.B., \& Gibbings, } \\
\text { E.N. (2013). Exploring best } \\
\text { practices in parenting } \\
\text { coordination: a national } \\
\text { survey of current practices } \\
\text { and practitioners. Family } \\
\text { Court Review, 51(4), 651- } \\
665 .\end{array}$ & $\begin{array}{l}\mathrm{N}=79 \mathrm{PCs} \\
\text { recruited via } \\
\text { an AFCC list- } \\
\text { serve. }\end{array}$ & $\begin{array}{l}\text { Cross-sectional } \\
\text { survey design }\end{array}$ & $\begin{array}{l}\text { Survey assessed } \\
\text { interventions into } \\
\text { three categories: } \\
\text { Assessment and } \\
\text { Conceptualization } \\
\text {; Education and } \\
\text { Intervention; and } \\
\text { Case and Conflict } \\
\text { Management }\end{array}$ & $\begin{array}{l}\text { Identifying the parenting } \\
\text { strengths and weaknesses, } \\
\text { assessing general co-parenting } \\
\text { skills, and consideration of } \\
\text { functioning and needs of } \\
\text { children involved were } \\
\text { assessed to be equally } \\
\text { effective; } \\
\text { Informing parents about the } \\
\text { developmental needs of their } \\
\text { children, teaching effective } \\
\text { communication skills for } \\
\text { parents, and providing } \\
\text { information on the effects of } \\
\text { high parental conflict on } \\
\text { children rated as being } \\
\text { generally effective; }\end{array}$ & $\begin{array}{l}\text { Representativenes } \\
\text { s of the sample is } \\
\text { limited. }\end{array}$ \\
\hline 7 & $\begin{array}{l}\text { Fieldstone, L., Carter, D.K., } \\
\text { King, T., \& McHale, J.P. } \\
\text { (2011). Training, skills, and } \\
\text { practices of parenting } \\
\text { coordinators: Florida } \\
\text { statewide study. Family } \\
\text { Court Review, 49, 801-817. }\end{array}$ & $\begin{array}{l}\mathrm{N}=67 \mathrm{PCs} \text { in } \\
\text { Florida (32\% } \\
\text { response rate); } \\
\text { mental health } \\
\text { professionals } \\
\text { and legal } \\
\text { professionals. }\end{array}$ & $\begin{array}{l}\text { Cross-sectional } \\
\text { descriptive } \\
\text { survey }\end{array}$ & $\begin{array}{l}\text { Survey gathering } \\
\text { data regarding } \\
\text { demographics } \\
\text { and PCs' } \\
\text { perceptions of } \\
\text { clients, } \\
\text { interventions }\end{array}$ & $\begin{array}{l}\text { PCs believe that their work was } \\
\text { successful. PC practices were } \\
\text { similar, important role of the } \\
\text { PC as an educator. }\end{array}$ & $\begin{array}{l}\text { Small sample size } \\
\text { limited to PCs in } \\
\text { Florida thus } \\
\text { limiting the } \\
\text { generalizability of } \\
\text { the study's } \\
\text { findings. }\end{array}$ \\
\hline
\end{tabular}


Cite as: $\quad$ Deutsch, M.R., Misca, G. and Ajoku, C. (2018) Critical review of research evidence of parenting coordination's effectiveness, Family Court Review, 56(1).

\begin{tabular}{|c|c|c|c|c|c|c|}
\hline \multicolumn{2}{|r|}{ Study (authors, year) } & \multirow[t]{2}{*}{ Participants } & \multirow[t]{2}{*}{ Study design } & \multirow[b]{2}{*}{$\begin{array}{l}\text { Measures }^{i} \\
\text { employed, factors } \\
\text { PCs believed } \\
\text { aided in the } \\
\text { success of the PC } \\
\text { process. }\end{array}$} & \multirow[t]{2}{*}{ Main findings } & \multirow[t]{2}{*}{ Limitations } \\
\hline & & & & & & \\
\hline 8 & $\begin{array}{l}\text { Fieldstone, L., Lee, M.C., } \\
\text { Baker, J.K., \& McHale, J.P. } \\
\text { (2012). Perspectives on } \\
\text { parenting coordination: } \\
\text { Views of parenting } \\
\text { coordinators, attorneys, } \\
\text { and judiciary members. } \\
\text { Family Court Review, } 50 \\
\text { (3), 441-454. }\end{array}$ & $\begin{array}{l}\mathrm{n}=17 \text { judges } \\
\text { and general } \\
\text { magistrates } \\
\text { ( } 52 \% \text { of } \\
\text { eligible } \\
\text { participants); } \\
\mathrm{n}=94 \text { family } \\
\text { law attorneys } \\
\text { whose clients } \\
\text { receive } \\
\text { parenting } \\
\text { coordination } \\
\text { (35\% of } \\
\text { eligible } \\
\text { participants); } \\
\mathrm{n}=23 \text { parent } \\
\text { coordinators } \\
\text { (comprising } \\
92 \% \text { of eligible } \\
\text { PCs). }\end{array}$ & $\begin{array}{l}\text { Cross-sectional } \\
\text { descriptive } \\
\text { survey } \\
\text { Timespan: } \\
\text { 2005-2010 }\end{array}$ & $\begin{array}{l}\text { The survey asked } \\
\text { participants } \\
\text { covering the } \\
\text { following } 10 \\
\text { areas: } 1 \text { ) } \\
\text { demographics } \\
\text { information; 2) } \\
\text { knowledge of PC } \\
\text { and perceptions; } \\
\text { 3) experience } \\
\text { with PCs; 4) PC } \\
\text { fees; 5) PCs' } \\
\text { relationships with } \\
\text { the court, 6) } \\
\text { Attorneys; 7) the } \\
\text { Parties; 8) } \\
\text { termination of } \\
\text { PC; 9) court's } \\
\text { response to PC; } \\
\text { and 10) effects of } \\
\text { the PC process. }\end{array}$ & $\begin{array}{l}\text { Participants had positive views } \\
\text { on parenting coordination. } \\
\text { Areas to improve perception of } \\
\text { and the effectiveness of PC: } 1 \text { ) } \\
\text { greater education about } \\
\text { parenting coordination; } 2 \text { ) } \\
\text { address the issues of PC fees; } \\
\text { 3) explore the role of a court } \\
\text { program; 4) resolution of } \\
\text { ethical issues; 5) PC in cases in } \\
\text { which IPV is a factor; and } 6 \text { ) } \\
\text { addressing factors important } \\
\text { to improving perception of the } \\
\text { PC process }\end{array}$ & $\begin{array}{l}\text { Participant } \\
\text { selection bias } \\
\text { explaining the } \\
\text { overall positive } \\
\text { view } \\
\text { Sample was } \\
\text { limited to judges, } \\
\text { attorneys, and PCs } \\
\text { in a single judicial } \\
\text { circuit (Miami- } \\
\text { Dade County, } \\
\text { Florida) thus } \\
\text { generalizability of } \\
\text { the results is } \\
\text { limited; } \\
\text { Time period 2005- } \\
\text { 2010, covers a } \\
\text { period before a PC } \\
\text { statute was } \\
\text { enacted. }\end{array}$ \\
\hline 9 & $\begin{array}{l}\text { Hirsch, B. P. (2016). } \\
\text { Parenting Coordinators' } \\
\text { Practices } \\
\text { Recommendations: A } \\
\text { Qualitative Study (MSc } \\
\text { dissertation, Virginia Tech). }\end{array}$ & $\begin{array}{l}\mathrm{N}=7 \text { mental } \\
\text { health } \\
\text { parenting } \\
\text { coordinators } \\
\text { (6 } \\
\text { psychologists }\end{array}$ & $\begin{array}{l}\text { Exploratory } \\
\text { Qualitative; } \\
\text { Thematic } \\
\text { analysis }\end{array}$ & $\begin{array}{l}\text { Face-to-face } \\
\text { interviews with } \\
\text { each participant } \\
\text { and } \\
\text { demographics } \\
\text { questionnaire } \\
\end{array}$ & $\begin{array}{l}\text { a number of practices used by } \\
\text { mental health PCs to educate } \\
\text { parents, improve the quality of } \\
\text { parenting and coparenting, } \\
\text { manage conflict, and involve } \\
\text { children and family members }\end{array}$ & $\begin{array}{l}\text { Small sample size } \\
\text { cannot be } \\
\text { generalized. }\end{array}$ \\
\hline
\end{tabular}


Cite as: $\quad$ Deutsch, M.R., Misca, G. and Ajoku, C. (2018) Critical review of research evidence of parenting coordination's effectiveness, Family Court Review, 56(1).

\begin{tabular}{|c|c|c|c|c|c|}
\hline Study (authors, year) & Participants & Study design & Measures $^{i}$ & Main findings & Limitations \\
\hline & $\begin{array}{l}\text { and one social } \\
\text { worker) with } \\
\text { at least three } \\
\text { years of } \\
\text { experience } \\
\text { from a } \\
\text { multidisciplina } \\
\text { ry family law } \\
\text { listserv in } \\
\text { Washington } \\
\text { DC area } \\
\text { including } \\
\text { Maryland and } \\
\text { Northern } \\
\text { Virginia. }\end{array}$ & & & $\begin{array}{l}\text { expands the recommended } \\
\text { practices that can be used for } \\
\text { training, peer support and } \\
\text { future studies to create } \\
\text { positive changes for the family. }\end{array}$ & \\
\hline $\begin{array}{l}10 \text { Mandarino, K., Kline } \\
\text { Pruett, M., \& Fieldstone, L. } \\
\text { (2016). Co-parenting in a } \\
\text { Highly Conflicted } \\
\text { Separation/Divorce: } \\
\text { Learning about Parents } \\
\text { and their Experiences of } \\
\text { Parenting Coordination, } \\
\text { Legal, and Mental Health } \\
\text { Interventions. Family Court } \\
\text { Review, 54(4), 564-577. }\end{array}$ & $\begin{array}{l}\mathrm{N}=60 \text { (parent) } \\
\text { from high } \\
\text { conflict } \\
\text { separated or } \\
\text { divorced } \\
\text { parents from } \\
\text { the United } \\
\text { States and } \\
\text { Canada of } \\
\text { which } 37 \text { were } \\
\text { involved with } \\
\mathrm{PC} \text { currently or } \\
\text { within the last } \\
\text { five years }\end{array}$ & & $\begin{array}{l}\text { Narcissistic } \\
\text { Personality } \\
\text { Inventory-16 } \\
\text { Toronto Empathy } \\
\text { Questionnaire } \\
\text { Acrimony Scale } \\
\text { Coparenting style } \\
\text { scale }\end{array}$ & $\begin{array}{l}\text { Parents who engaged in PC } \\
\text { reported they: learned useful } \\
\text { skills ( } 30 \%) \text {; focused on the } \\
\text { child's best interests ( } 26 \%) ; \\
22 \% \text { were satisfied with the } \\
\text { knowledge and experience of } \\
\text { their PC and their neutrality } \\
(13 \%) . \text { Parents were } \\
\text { dissatisfied by lack of efficiency } \\
(27 \%), \text { lack of a working } \\
\text { alliance }(13 \%) \text { and } 20 \% \text { felt } \\
\text { their practitioner was } \\
\text { unprofessional or unqualified. }\end{array}$ & $\begin{array}{l}\text { Selection bias - } \\
\text { data from just one } \\
\text { of the coparents } \\
\text { who self selected } \\
\text { to participate and } \\
\text { may not reflect an } \\
\text { objective view of } \\
\text { the coparenting } \\
\text { relationship }\end{array}$ \\
\hline
\end{tabular}


Cite as: $\quad$ Deutsch, M.R., Misca, G. and Ajoku, C. (2018) Critical review of research evidence of parenting coordination's effectiveness, Family Court Review, 56(1).

\begin{tabular}{|c|c|c|c|c|c|c|}
\hline & Study (authors, year) & Participants & Study design & Measures ${ }^{i}$ & Main findings & Limitations \\
\hline & $\begin{array}{l}\text { Brewster, K. O. H., Beck, C. } \\
\text { J., Anderson, E. R., \& } \\
\text { Benjamin, G. A. H. (2011). } \\
\text { Evaluating parenting } \\
\text { coordination programs: } \\
\text { Encouraging results from } \\
\text { pilot testing a research } \\
\text { methodology. Journal of } \\
\text { Child Custody, 8(4), 247- } \\
267 .\end{array}$ & $\begin{array}{l}\mathrm{N}=21 \text { cases } \\
\text { that } \\
\text { participated in } \\
\text { the } \mathrm{PC} \\
\text { program for a } \\
\text { 2-year period }\end{array}$ & $\begin{array}{l}\text { Longitudinal } 2 \\
\text { year follow up } \\
\text { design; }\end{array}$ & $\begin{array}{l}\text { The use of courts } \\
\text { and outside } \\
\text { agencies assessed } \\
\text { via documents in } \\
\text { the archived } \\
\text { divorce files for } \\
\text { the } 2 \text { years prior } \\
\text { to the } \\
\text { appointment of } \\
\text { the PC. }\end{array}$ & $\begin{array}{l}\text { In the 2-year period after the } \\
\text { appointment of the PC there } \\
\text { was a significant } \\
\text { reduction in the number of } \\
\text { legal documents in the files, } \\
\text { hearings, } \\
\text { changes in the parenting plan } \\
\text { and } \\
\text { a reduction in the use of } \\
\text { outside agencies. }\end{array}$ & $\begin{array}{l}\text { Small sample size; } \\
\text { limited variability } \\
\text { in the experience } \\
\text { and professional } \\
\text { training of the } \\
\text { PCs. }\end{array}$ \\
\hline & $\begin{array}{l}\text { Henry, W.J., Fieldstone, L., } \\
\text { \& Bohac, K. (2009). } \\
\text { Parenting coordination and } \\
\text { court relitigation: A case } \\
\text { study. Family Court } \\
\text { Review, } 47 \text { (4), 682-697. }\end{array}$ & $\begin{array}{l}\mathrm{N}=49 \text { Couples } \\
\text { randomly } \\
\text { selected from } \\
\text { cases ordered } \\
\text { to utilize } \\
\text { parenting } \\
\text { coordination } \\
\text { during the } \\
2006 \text { calendar } \\
\text { year based on } \\
\text { availability of } \\
\text { relevant court } \\
\text { records. }\end{array}$ & $\begin{array}{l}\text { Case study } \\
\text { research } \\
\text { design. }\end{array}$ & $\begin{array}{l}\text { Public case files } \\
\text { and court } \\
\text { documents } \\
\text { containing } \\
\text { information } \\
\text { regarding } \\
\text { demographics, } \\
\text { number of years } \\
\text { in litigation, and } \\
\text { the number of } \\
\text { motions filed in } \\
\text { the relevant } \\
\text { timeframes. }\end{array}$ & $\begin{array}{l}\text { A reduction of } 75 \% \text { in child- } \\
\text { related court filings and a } 40 \% \\
\text { on other motions, resulting in } \\
\text { a } 50 \% \text { reduction in all motions } \\
\text { filed. Over } 60 \% \text { of the co- } \\
\text { parenting pairs filed less } \\
\text { motions within the first year of } \\
\text { receiving parenting } \\
\text { coordination services. }\end{array}$ & $\begin{array}{l}\text { Data was obtained } \\
\text { from only one } \\
\text { court system, } \\
\text { thus, participants } \\
\text { may not be } \\
\text { reflective of high } \\
\text { conflict dyads, } \\
\text { court mandated to } \\
\text { parenting } \\
\text { coordination, } \\
\text { across the nation. } \\
\text { The case study } \\
\text { research design } \\
\text { does not explore } \\
\text { other variables } \\
\text { that might } \\
\text { account } \\
\text { for/explain the } \\
\text { reduction in } \\
\text { motions filed. } \\
\text { Lack of a control } \\
\text { group (e.g. dyads }\end{array}$ \\
\hline
\end{tabular}


Cite as: $\quad$ Deutsch, M.R., Misca, G. and Ajoku, C. (2018) Critical review of research evidence of parenting coordination's effectiveness, Family Court Review, 56(1).

\begin{tabular}{|c|c|c|c|c|c|c|}
\hline \multicolumn{2}{|r|}{ Study (authors, year) } & Participants & Study design & Measures $^{i}$ & Main findings & Limitations \\
\hline & & & & & & $\begin{array}{l}\text { that did not } \\
\text { receive PC } \\
\text { services). }\end{array}$ \\
\hline 13 & $\begin{array}{l}\text { a) Scott, M., Ballard, F., } \\
\text { Sawyer, C., Ross, T., } \\
\text { Burkhauser, M., Ericson, S., } \\
\text { \& Lilja, E. (2010). The } \\
\text { Parenting Coordination } \\
\text { (PC) Project } \\
\text { implementation and } \\
\text { outcomes study report. } \\
\text { Washington, DC: Child } \\
\text { Trends, American } \\
\text { Psychological Association; } \\
\text { Lally, S. J., \& Higuchi, S. A. } \\
\text { (2008). The American } \\
\text { Psychological Association } \\
\text { Parenting Coordination } \\
\text { Project: Development of } \\
\text { the project and initial } \\
\text { review of the first two } \\
\text { years. Journal of Child } \\
\text { Custody, 5, 101-121. } \\
\text { doi:10.1080/15379410802 } \\
\text { 070435 }\end{array}$ & $\begin{array}{l}\mathrm{N}=42 \text { parents } \\
\text { ( } 21 \text { families) }\end{array}$ & $\begin{array}{l}\text { Pre- and post- } \\
\text { test design }\end{array}$ & $\begin{array}{l}\text { Outcome } \\
\text { measures: } \\
\text { Parenting Alliance } \\
\text { Measure (PAM); } \\
\text { Acrimony Index; } \\
\text { Child Behavior } \\
\text { Checklist (CBCL); } \\
\text { Satisfaction } \\
\text { Survey, } \\
\text { Parenting } \\
\text { Coordination } \\
\text { Record. }\end{array}$ & $\begin{array}{l}\text { Statistically significant } \\
\text { relationship between } \\
\text { participation in the PC program } \\
\text { and a reduction in the burden } \\
\text { on court resources; } \\
\text { parent's perceptions of their } \\
\text { relationship with one another } \\
\text { and their children's behavior, } \\
\text { were not statistically } \\
\text { significant; } \\
\text { Fathers reported statistically } \\
\text { significant levels of affective } \\
\text { problems for children aged 6- } \\
18 \text { and statistically significant } \\
\text { lower levels of post-traumatic } \\
\text { stress problems for their } \\
\text { children. }\end{array}$ & $\begin{array}{l}\text { Small sample size; } \\
\text { cannot draw } \\
\text { causal } \\
\text { relationships. } \\
\text { attrition (not all of } \\
\text { the pre-test } \\
\text { parents } \\
\text { completing the } \\
\text { post-test survey) }\end{array}$ \\
\hline
\end{tabular}

\footnotetext{
See original source for citations and full details of the measures used in the reviewed studies.
} 